\title{
The Community Participation in the Implementation of Diversion at Investigation Level
}

\author{
Dian Rahmawati*) and Bambang Tri Bawono ${ }^{* *}$ ) \\ ${ }^{*}$ C Class I Penitentiary of Semarang, E-mail:dian07101991@gmail.com \\ ${ }^{* *}$ ) Faculty Of Law, Sultan Agung Islamic University
}

\begin{abstract}
This study aims to determine the role of the community in the implementation of diversion at the level of investigation that is important as a way of resolving cases of children who are in conflict with the law. This research was carried out in the city of Semarang, Central Java by selecting institutions relevant to the problem in this journal, namely the Class I Penitentiary Semarang by using a research method in the form of the Sociological Juridical method. The research specifications used were descriptive analytical. The data sources were obtained from primary data sources and secondary data with data collection carried out by means of field studies by conducting interviews supported by literature studies. From the research conducted, the authors get the following results, The role of community members in implementing diversion is very important because apart from being mandated by Act No. 11 of 2012, community members also implement Community Based Corrections (CBC); community participation can increase the effectiveness and efficiency of the settlement of children's cases; Community participation in the implementation of diversion is an effort to protect children and protect the community itself.

Keywords: Children; Diversion; Investigation; Society.
\end{abstract}

\section{Introduction}

Currently, violations of the law are not only committed by adults. However, it is also carried out by minors. Children are an inseparable part of human survival and the survival of a nation. ${ }^{1}$ Reality in social life shows that unlawful acts or behavioral deviations by children are getting higher and lead to other crimes.

Guidance in prison is a form of criminal sanction that is popular in Indonesian society. The public has the perception that imprisoning criminals is the best solution in resolving criminal cases, both adults and children. According to M. Nasir Djamil, some of the bad effects of imprisonment for children include stigmatization/labeling of criminals/convicts and the imprisonment of children with adults placing children in situations prone to being victims of violence. ${ }^{2}$

Based on data from the Directorate General of Corrections of the Ministry of Law and Human Rights of the Republic of Indonesia in September 2021, it shows a worrying condition, as many as 30 Regional Offices of the Ministry of Law and Human Rights out of a total of 33 Regional Offices are provinces with over-capacity prisons/detention centers. And what is even more surprising is the high number of children in prisons/remand centers scattered throughout the country. There were 1276 male prisoners, 21 female prisoners, 328 male prisoners and 88 female prisoners. So as many as 1713 children live in prisons / detention centers, while the

\footnotetext{
${ }^{1}$ SetyaWahyudi, 2011, Implementasi Ide Diversi Dalam Pembaharuan Sistem Peradilan Anak Di Indonesia, Yogyakarta: Genta Publishing, p. 34.

2 M.Nasir Djamil, 2015, Anak Bukan untuk Dihukum, Jakarta: Sinar Grafika, p 3-4.
} 
number of Special Child Correctional Institutions (LPKA) is only 33 units. ${ }^{3}$ From the data above, it shows that there are still many inmates or child detainees who are imprisoned with inmates or adult prisoners in one Correctional Institution. of course it will have a negative impact on child prisoners or child prisoners.

Indonesia as a state of law (Rechstaat) as stated in the state constitution Article 1 Paragraph (3) of the 1945 Constitution, this provides a strong legal basis for the enforcement of the rule of law which is evident in every element of community life. Especially problems related to children, as the orientation of our thinking is the one who commits a crime or against the law. In the constitution of the Indonesian nation, children have a strategic role that is expressly it is stated that the state guarantees every child's rights to survival, growth and development of protection from violence and acts of discrimination. Thus it is clear, the consequences of the provisions of Article 28B of the 1945 Constitution get an appreciation that needs to be followed up by making a policy government which aims to protect children involved in various legal cases. ${ }^{4}$

The development of the law that is getting tougher and more prominent shows that law is a modern concept, which should not only be seen as a means to make changes. Thus, law does not only show established values, or is only seen as an act of issuing formal regulations. ${ }^{5}$

Currently, the criminal system is seriously regulating the protection of criminal law against children, which if the child is a criminal, the imposition of punishment on him certainly cannot be equated with adults as perpetrators of crime. ${ }^{6}$ This effort to protect children can be seen in the promulgation of Act No. 11 of 2012 concerning the Juvenile Criminal Justice System which was effectively enforced on July 31, 2014.

Based on Restorative Justice Theory / Restorative Justice, Restorative justice is justice that applies in the non-litigation dispute resolution process (Alternative Dispute Resolution), the focus is not on the perpetrator, but the victim. Restorative Justice aims to empower victims, perpetrators, families and communities to correct an act against the law, using awareness and conviction as a basis for improving community life; the concept of justice which does not only see justice from one side, but judges it from the interests of various parties, both the interests of the victim, the community and the interests of the perpetrator. ${ }^{7}$

Diversion is the spirit of restoration justice in the Juvenile Criminal System, while deliberation is a driving factor in the implementation of Diversion, because deliberation is a characteristic of Indonesian people who like to live in groups. In solving problems, the Indonesian people use Deliberation so as to produce the best

\footnotetext{
${ }^{3}$ http://smslap.ditjenpas.go.id/public/grl/current/daily, accessed on 15 September 2021.

${ }^{4}$ I Dewa Putu Gede Anom Danujaya, "Formulasi Model Sistem Pemidanaan Anak Di Indonesia", Jurnal Daulat Hukum, Vol 1, No 1 2018: March 2018, p. 108

${ }^{5}$ Esmi Warassih, 2016, Pranata Hukum Sebuah Telaah Sosiologis, Semarang: Pustaka Magister, 29.

${ }^{6}$ Nandang Sambas, 2010, Pembaharuan Sistem Pemidanaan Anak di Indonesia, Yogyakarta: Graha Ilmu, 25.

7 Bahan Ajar Pelatihan terpadu Sistem Peradilan Pidana Anak, 2017, Jakarta: Press Media, p.114.
} 
solution according to consensus agreement for the common interest and must be obeyed by every member of the community 8 .

Thus, it is not surprising that in the implementation of diversion and the implementation of the diversion provisions as contained in the Republic of Indonesia Act No. 11 of 2012 concerning the Juvenile Criminal Justice System, the community involves a lot of people. So based on the description above, it is important to conduct research on Community Participation in the Implementation of Diversion at the Investigation Level.

The problem that can be formulated is Why is the role of the community in the implementation of diversion at the investigation level important as a way of resolving cases of children who are in conflict with the law? The purpose of this study was to determine the role of the community in the implementation of diversion at the investigation level, which is important as a way of resolving cases of children in conflict with the law.

\section{Research Methods}

This study uses a sociological juridical problem approach. The sociological juridical approach is to identify and conceptualize law as a real and functional social institution in a real life system ${ }^{9}$. The sociological juridical approach emphasizes research that aims to obtain legal knowledge empirically by going directly to the object, namely to find out the role of society in the implementation of diversion at the investigative level, which is important as a way of resolving cases of children dealing with the law. The research specification used is descriptive analytical. The sources of data obtained from primary data sources and secondary data. And primary data collection through field studies by conducting interviews with the Community Counselor at the Correctional Center then secondary data is carried out by means of literature studies, namely laws and regulations, especially those related to diversion, namely the Republic of Indonesia Act No. 11 of 2012 concerning the Juvenile Criminal Justice System.

\section{Results and Discussion}

\subsection{The Juvenile Criminal Justice System in Indonesia is obliged to seek the settlement of children's cases with a restorative justice approach}

Juridically, juvenile delinquency in Indonesia has obtained standard guidelines which are regulated in Article 1 paragraph 2 of the Republic of Indonesia Act No. 11 of 2012 concerning the Juvenile Criminal Justice System. 12 (twelve) years old, but not yet 18 (eighteen) years old who are suspected of committing a crime. Children who are victims of criminal acts, hereinafter referred to as Child Victims and children who are witnesses to criminal acts, hereinafter referred to as Child Witnesses.

\footnotetext{
${ }^{8}$ Chuasanga A., Ong Argo Victoria, 2019. "Legal Principles Under Criminal Law in Indonesia and $\begin{array}{lllllll}\text { Thailand", Jurnal Daulat Hukum, Vol 2, No } 1 & \text { (2019) }\end{array}$ http://jurnal.unissula.ac.id/index.php/RH/article/view/4218 ${ }^{9}$ Ibid., p. 51.
} 
Article 1 paragraph 6 of the Republic of Indonesia Act No. 11 of 2012 concerning the Juvenile Criminal Justice System states that Restorative Justice is the settlement of criminal cases by involving the perpetrator, victim, family of the perpetrator/victim, and other related parties to jointly seek a fair solution by emphasizing restoration to its original state, and not retaliation.

The implementation of diversion is motivated by the desire to avoid negative effects on the soul and body development of the child by his involvement with the criminal justice system. Implementation of diversion by Law enforcement officers are based on the authority of law enforcement officers which is called discretion or discretion in Indonesian discretion. With the application of the concept of diversion of existing forms of formal justice So far, it has prioritized efforts to provide protection for children from actions imprisonment. The state has the discretionary authority to divert (diversion) children who conflict with the law from the formal criminal justice process to the peace process outside the judge. Wherever possible, children are avoided from arrest, detention and imprisonment, it should be a last resort. Diversion is a discretionary process that components of the criminal justice system (Police, Prosecutors, Courts) aimed at to children in conflict with the law. Diversion is a policy carried out to keep perpetrators out of the formal criminal justice system. ${ }^{10}$

The concept of restorative justice is the process of resolving legal violations that occur by bringing victims and legal actors (suspects) together to sit in a meeting to talk together. During the meeting, the mediator gave a clear picture of the actions he had taken. ${ }^{11}$

Justice that has been taking place in the criminal justice system in Indonesia is retributive justice. While what is expected is restorative justice, namely justice is a process in which all parties involved in a particular crime jointly resolve the problem of how to deal with future consequences. Restorative justice is a model for resolving criminal cases that prioritizes the recovery of victims, perpetrators and the community. The main principle of restorative justice is the participation of victims and perpetrators, the participation of citizens as facilitators in resolving cases, so that there is a guarantee that the child or perpetrator will no longer interfere with the harmony that has been created in society. ${ }^{12}$

\subsection{Restorative justice implemented concretely in the settlement of children's cases through the implementation of diversion}

Diversion attempts are set in Act No. 11 of 2012 concerning the Juvenile Criminal Justice System, which in Article 1, namely the handling of children who are in conflict with the law by implementing diversion or transfer settlement of children's cases from the criminal justice process to the process outside the criminal justice stated in the Act No. 11 of 2012 Article 5 paragraph (3) hereinafter referred

\footnotetext{
10 Fiska Ananda, "Penerapan Diversi Sebagai Upaya Perlindungan Hukum Terhadap Anak Pelaku Tindak Pidana", Jurnal Daulat Hukum, Vol 1, No 1 2018: March 2018, p. 79

11 Marlina, 2012, Peradilan Anak di Indonesia: Pengembangan Konsep Diversi dan Restorative Justice, Bandung: PT Refika Aditama, p. 180-181.

${ }^{12 N u g r a h a ~ a n d ~ S u k a r m i ~ " R e s t o r a t i v e ~ J u s t i c e ~ i n ~ S e t t l e m e n t ~ o f ~ C r i m i n a l ~ A c t i o n ~ o f ~ G r i e v a n t ~ D e l i c i o n ", ~}$ Law Development Journal, Vol 2, No 4 (2020): December 2020, p. 551.
} 
to as the juvenile criminal justice system, which emphasizes the criminal justice system children must be sought for diversion. Diversion is closely related to the protection of human rights because on the side of the perpetrator, penal mediation provides an opportunity for the perpetrator to improve himself, admit his actions and take responsibility for what he did. Implementation policy (Applicative Policy) legal mediation includes legal mediation outside the criminal justice process (Law Mediation Out of Criminal Justice Process), and legal mediation in the criminal justice process (Law Mediation Within Criminal Justice System) which includes the mediation function at the investigation stage, prosecution, examination before the court. ${ }^{13}$

In the implementation of diversion, interactions occur between conflicting parties, community counselors, social workers, and the community. They consulted to get an agreement called the Diversion Agreement, which was determined by the local District Court to have an element of legal certainty and was binding on all parties involved in it. Marlina said that diversion in the United States is known as the neighborhood program. This program is designed to consider children who are at high risk of being in the criminal justice system. This policy is designed based on the tradition of community service. This program is carried out with the aim of reducing delinquency by providing mental counseling/guidance activities, health measures, opportunities for work, recreation, ${ }^{14}$

Diversion is the transfer of settlement of children's cases from the criminal justice process to processes outside of criminal justice. According to Marlina, diversion is carried out with the reason to provide an opportunity for law violators to become good people again through non-formal channels by involving community resources. Although the implementation of diversion is one of the efforts to protect children by the state, it is not as broad as cases of criminal acts by children can be resolved through diversion. This is because there are special conditions that a child's case can be resolved through the implementation of diversion, this requirement is regulated in Article 7 paragraph 2 of the Republic of Indonesia Act No. 11 of 2012 concerning the Juvenile Criminal Justice System.

Article 7 of the Act No. 11 of 2012 concerning the Juvenile Criminal Justice System states that:

- Every Investigator, Public Prosecutor, and Judge in examining a Child is obliged to seek Diversion.

- The diversion as referred to in paragraph (1) is carried out in the event that a criminal act is committed: Threatened with imprisonment under 7 (seven) years; and It is not a repetition of a crime.

Law enforcement officers are required to seek the resolution of juvenile crimes through diversion at every stage of the criminal justice system, namely at the level of investigation, prosecution and examination in district courts, in accordance with Article 7 paragraph 1 of Act No. 11 of 2012 concerning the Juvenile Criminal Justice

\footnotetext{
13 Rendy Surya Aditama, Umar Ma'ruf and Munsharif Abdul Chalim, "Kebijakan Hukum Pidana Terhadap Anak Sebagai Pelaku Kejahatan Psikotropika Di Kepolisian Resor Magelang", Jurnal Daulat Hukum, Vol 1, No 1 2018: March 2018, p. 121.

14 Marlina, 2012, Peradilan Anak di Indonesia: Pengembangan Konsep Diversi dan Restorative Justice, Bandung: PT Refika Aditama, p. 12-13.
} 
System. The law is in charge of serving the community, not the other way around. The quality of a law is determined by its ability to serve human welfare. This sentence seems to imply us to return to the flow of utilitarianism Jeremy Bentham which states that the purpose of law is to achieve "the greatest happiness for the greatest number of people". 15

There are two types of diversion implementation models according to the Republic of Indonesia Act No. 11 of 2012 concerning the Juvenile Criminal Justice System, the implementation of which is regulated in PP Number 65 of 2015 namely:

- Diversion without the victim's consent

PP Number 65 of 2015 Article 7 paragraph (1)

The Diversion Agreement can be made without the consent of the victim and/or the Child's family, if:

- Criminal acts in the form of violations;

- Minor crime;

- Crime without victims; or

- The value of the victim's loss is not more than the value of the local provincial minimum wage.

- Diversion with the victim's consent

The implementation of this model Diversion discussion involves the Investigator, Child and/or parent/Guardian, victim or Child Victim and/or parent/Guardian, Community Counselor, and Professional Social Worker. If desired, the implementation of diversion can involve the community consisting of religious leaders, teachers, community leaders, assistants or advocates/legal aid providers, and members of Non-Governmental Organizations.

Deliberation is a form of law as nomos, Soetandiyo Wignyosoebroto in Esmi Warassih (2015), explains that the face of nomos law is the face of law in social reality. Such a legal concept displays the face of law as regularities (behavior patterns). Law as nomos appears in two different typologies, namely: first, law appears as a real and functional social institution in the system of people's lives, both in the processes of restoring order and resolving disputes as well as in the processes of directing and forming new patterns of behavior. . Second, the face of law that can appear as symbolic meanings as manifested and observed in the actions and interactions of society. ${ }^{16}$

After the parties have finished deliberation to produce an agreement which is referred to as a diversion agreement. The diversion agreement is then ratified by the District Court, referred to as a diversion decision. The forms of the diversion agreement as regulated in Article 10 paragraph 2 and Article 11 of the Act No. 11 of 2012 concerning the Juvenile Criminal Justice System include reimbursement of losses in the event of a victim, reconciliation with or without compensation; medical and psychosocial rehabilitation; handover to parents/guardians; participation in education or training in educational institutions or LPKS; and community service.

\footnotetext{
15 Esmi Warassih, 2020, Sosiologi Hukum Sebagai Pengantar Dimensi Hukum dan Masyarakat, Yogyakarta: Literasi, p. 158.

16 Esmi Warassih, 2015, Pranata Hukum Sebuah Telaah Sosiologis, Semarang: Penerbit Pustaka Magister, p. vii.
} 
Proses diversion carried out by Central Java Police investigators as a whole have complied with the provisions of Act No. 11 of 2012 concerning the Juvenile Criminal Justice System. The diversion process involves all interested parties, namely the victim's family, the perpetrator's family, the Fathers, and the school principal. This matter in accordance with the provisions of Article 8 of Act No. 11 of 2012 concerning the Criminal Justice System The child has determined the procedures and procedures for diversion, which is carried out through deliberation by involving the child and his/her parents/guardians, victims and/or parents/guardians, mentors community, and Professional Social Worker based on a restorative justice approach. Deliberations can involve social welfare personnel, teachers, and community leaders. After the occurrence of a diversion agreement, then the investigator submits a request for a diversion determination to the Chairman of the Semarang District Court. After the letter of determination is issued, then SP3 is made. This is in accordance with the provisions of Article 12 of the SPPA Law. The diversion process is carried out to create restorative justice, both for children and for children victim. Restorative justice is a diversion process, that is, all parties involved in a certain crime together to solve the problem and create an obligation to make things better by involving victims, children, and community in finding solutions to repair, reconciliation, and reassurance that not based on revenge. ${ }^{17}$

Based on the description above, the settlement of children's cases through the implementation of diversion as a manifestation of the implementation of the Republic of Indonesia Act No. 11 of 2012 concerning the Juvenile Criminal Justice System is a legal method with a legal pluralism approach. According to Suteki, in general, the conception of legal pluralism requires a diversity approach in law because of the context of the plurality of society in the form of ethnic groups. Culture, race, religion, class and gender. In the development of legal pluralism, it is understood as the interaction between various state legal systems, customs, religions and other habits that are considered as law. The conception of legal pluralism emphasizes that people have their own way of ruling in accordance with their sense of justice and their needs in regulating their social relations. ${ }^{18}$

According to Arif Agung Prasetya as the First Community Counselor at the Class I Correctional Center Semarang, the community is the main actor in the Community Diversion Program (CDP). The implementation of diversion held for Child Clients at the Fathers Center, since the enactment of the RI Act No. 11 of 2012 concerning the Juvenile Criminal Justice System, effectively starting on July 31, 2014 always involves community members. The community consists of community leaders (Chairman of RT, Head of RW, Village Head, Head of Dat, etc.), religious leaders (Ustadz, Ustadzah, Pastor, etc.), teachers at Children's schools both in the

\footnotetext{
17 Anita Indah Setyaningrum, Diversi Sebagai Bentuk Penyelesaian Perkara Pidana Anak Melalui Pendekatan Restorative Justice Oleh Penyidik Polda Jawa Tengah, Jurnal Hukum khaira Ummah Unissula, Vol 12, No 4 (2017): October 2017, p. 4.

18 Suteki and Galang Taufani, 2018, Metodelogi Penelitian Hukum (Filsafa, Teori dan Praktik), Depok: Rajawali Pers, p. 39.
} 
process before Diversion, during Diversion deliberations until the implementation of the determination Diversion. ${ }^{19}$

Community involvement in the implementation of diversion is an effort to enforce the law on the Juvenile Criminal Justice System. Lawrence M Friedman suggests three elements that must be considered in law enforcement, the three elements include structure, substance and legal culture. ${ }^{20}$

\subsubsection{Legal Substance}

The substance of the law includes all the rules, both written and unwritten, both material law and formal law. ${ }^{21}$ The community has a strategic role in the implementation of diversion. This community involvement is regulated in the Republic of Indonesia Act No. 11 of 2012 concerning the Juvenile Criminal Justice System and Government Regulation Number 65 of 2015. Article 6 letter d of the Republic of Indonesia Act No. 11 of 2012 concerning the Juvenile Criminal Justice System mandates the community to play an active role in Juvenile criminal justice system, especially in the implementation of diversion. One of the objectives of implementing diversion is to encourage the participation of community members in resolving child cases. Therefore, law enforcement officers need to coordinate with community members, including families, community leaders, religious leaders and teachers to be involved in the implementation of diversion.

\subsubsection{Legal Structure}

The legal structure is closely related to the judicial system carried out by law enforcement officers, in the criminal justice system, law enforcement applications are carried out by investigators, prosecutors, judges and advocates. ${ }^{22}$ The legal structure shows how the law is carried out according to its formal provisions. This structure shows how investigators, community advisors and community members work together to carry out their functions in implementing diversion at the investigation level.

At each stage of the implementation of community diversion has a different position. At the diversion deliberation stage, the community is located as a participant in the diversion deliberations, while at the diversion deliberations implementation stage, the community is positioned as a community guiding partner to carry out correction/supervision of children in conflict with the law.

According to Jeffrey A Butts, one form of Community Based Corrections is informal diversion. ${ }^{23}$ Community Based Corrections is a general term used to refer to non-institutional coaching programs against law violators. According to Belinda Rodgers McCarthy and Bernard J McCarthy Community Based Corrections are activities that refer to various types of therapy, support and supervision programs

\footnotetext{
19 The results of an interview with Arif Agung Prasetya as the First Social Advisor at the Class I Correctional Center Semarang on October 18, 2021

${ }^{20}$ Lawrence M Friedman in Salim HS and Erlies Septiana Nurbani, 2013, Penerapan Teori Hukum pada Penelitian Tesis dan DIsertasi, Jakarta: PT Raja Grafindo Persada, p. 305.

21 Ibid, p. 12-16.

${ }^{22}$ Lawrence M. Friedman, 1975, The Legal System; A Social Science Prespective, New York: Russel Sage Foundation, p. 12-16.

${ }_{23}^{2}$ Jeffrey A Butts, 2015, Community Diversion Program, Jakarta: Gama Media, p. 529
} 
for lawbreakers. ${ }^{24}$ The purpose of the treatment of prisoners in Indonesia began in 1964 after Sahardjo stated in a prison conference, so that those who were prisoners were no longer made a deterrent but were fostered and then re-socialized.

\subsubsection{Legal Culture}

Legal culture is an emphasis on culture in general, habits, opinions, ways of acting and thinking, which direct social forces in society. According to Satjipto Rahardjo in Suteki, law making is strongly influenced by formal subjects (law making parties) and their affiliation with sociological variables (social background, education, economy, religion, belief, politics, family, etc.) who is the enforcer of the law, who is on trial, what is his social position, what is his economic position, etc.). ${ }^{25}$

Settlement of children's cases through the implementation of diversion is law enforcement in a "typical" way. This peculiarity can be seen in the results of the diversion agreement that was born from the diversion deliberation. The "typical" nature of the substance of the diversion agreement reflects the social, religious, economic, educational and cultural conditions of the conflicting community members. Thus the diversion agreement is a positive law drawn up by the people involved in diversion using legal materials that live in the community/living law (moral, ethical, religion) and bind the people who make it.

Thus, it can be concluded that the role of the community in the implementation of diversion is important as an effective and efficient law enforcement effort. The role of the community as participants in the diversion deliberation is able to bring justice, certainty and benefit to all parties. The role of the community as law enforcement officers in carrying out Community Based Corrections can save the state budget in the correctional sector. So that the involvement of the community in the implementation of diversion can increase the effectiveness and efficiency of child criminal law enforcement.

\section{Closing}

From the above writing, it can be concluded that the participation of the community in the implementation of diversion is very important because apart from being mandated by the Act No. 11 of 2012, community members also implement Community Based Corrections (CBC); community participation can increase the effectiveness and efficiency of the settlement of children's cases; Community participation in the implementation of diversion is an effort to protect children and protect the community itself. Given the importance of the role of community members in the implementation of diversion, the authors provide suggestions: For law enforcement officials and the government to socialize the importance of community participation in the implementation of diversion as a way of resolving child cases which is the implementation of restoration justice and Community Based Corrections, for the realization of law enforcement goals and objectives penitentiary system. And so that law enforcement officers always encourage community involvement in the implementation of diversion as a settlement of cases of children

\footnotetext{
${ }^{24}$ Andi Wijaya Rivai, 2014, Buku Pintar Pemasyarakatan, Jakarta: Lembaga Kajian Pemasyarakatan, p. 20.

${ }^{25}$ Suteki, 2015, Masa Depan Hukum Progresif, Yogyakarta: Thafa Media, p.85.
} 
in conflict with the law. Law enforcement officials can coordinate with village officials, community leaders, schools and religious leaders.

\section{References}

\section{Journals:}

[1] Anita Indah Setyaningrum, Diversi Sebagai Bentuk Penyelesaian Perkara Pidana Anak Melalui Pendekatan Restorative Justice Oleh Penyidik Polda Jawa Tengah, Jurnal Hukum khaira Ummah Unissula, Vol 12, No 4 (2017): October 2017.

[2] Chuasanga A., Ong Argo Victoria. (2019). Legal Principles Under Criminal Law in Indonesia and Thailand, Jurnal Daulat Hukum, Vol 2, No 1 (2019) http://jurnal.unissula.ac.id/index.php/RH/article/view/4218

[3] Fiska Ananda, "Penerapan Diversi Sebagai Upaya Perlindungan Hukum Terhadap Anak Pelaku Tindak Pidana”, Jurnal Daulat Hukum Unissula, Vol 1, No 1 2018: March 2018.

[4] I Dewa Putu Gede Anom Danujaya, "Formulasi Model Sistem Pemidanaan Anak Di Indonesia", Jurnal Daulat Hukum Unissula, Vol 1, No 1 2018: March 2018.

[5] Nugraha and Sukarmi "Restorative Justice in Settlement of Criminal Action of Grievant Delicion", Law Development Journal Unissula, Vol 2, No 4 (2020): December 2020.

[6] Rendy Surya Aditama, Umar Ma'ruf, Munsharif Abdul Chalim, “Kebijakan Hukum Pidana Terhadap Anak Sebagai Pelaku Kejahatan Psikotropika Di Kepolisian Resor Magelang", Jurnal Daulat Hukum Unissula, Vol 1, No 12018 : March 2018.

\section{Books:}

[1] Andi Wijaya Rivai, 2014, Buku Pintar Pemasyarakatan, Jakarta: Lembaga Kajian Pemasyarakatan.

[2] Bahan Ajar Pelatihan terpadu Sistem Peradilan Pidana Anak, 2017, Jakarta: Press Media.

[3] Esmi Warassih, 2015, Pranata Hukum Sebuah Telaah Sosiologis, Semarang: Penerbit Pustaka Magister.

[4] Esmi Warassih, 2016, Pranata Hukum Sebuah Telaah Sosiologis, Semarang: Pustaka Magister.

[5] Esmi Warassih, 2020, Sosiologi Hukum Sebagai Pengantar Dimensi Hukum dan Masyarakat, Yogyakarta: Literasi.

[6] Jeffrey A Butts, 2015, Community Diversion Program, Jakarta: Gama Media.

[7] Lawrence M Friedman in Salim HS and Erlies Septiana Nurbani, 2013, Penerapan Teori Hukum pada Penelitian Tesis dan DIsertasi, Jakarta: PT Raja Grafindo Persada.

[8] Lawrence M. Friedman, 1975, The Legal System; A Social Science Prespective, New York: Russel Sage Foundation.

[9] M.Nasir Djamil, 2015, Anak Bukan untuk Dihukum,Jakarta: Sinar Grafika.

[10] Marlina, 2010, Pengantar Konsep Diversi dan restorative Justice Dalam Hukum Pidana, Medan: Usu Press. 
[11] Marlina, 2012, Peradilan Anak di Indonesia: Pengembangan Konsep Diversi dan Restorative Justice, Bandung: PT Refika Aditama.

[12] Nandang Sambas, 2010, Pembaharuan Sistem Pemidanaan Anak di Indonesia, Yogyakarta: Graha Ilmu.

[13] SetyaWahyudi, 2011, Implementasi Ide Diversi Dalam Pembaharuan Sistem Peradilan Anak Di Indonesia, Yogyakarta: Genta Publishing.

[14] Suteki and Galang Taufani, 2018, Metodelogi Penelitian Hukum (Filsafa, Teori dan Praktik, Depok: Rajawali Pers.

[15] Suteki, 2015, Masa Depan Hukum Progresif, Yogyakarta: Thafa Media.

\section{Internet:}

[1] http://smslap.ditjenpas.go.id/public/grl/current/daily,accessed on 15 September 2021. 